\title{
Marinobacterium halophilum sp. nov., a marine bacterium isolated from the Yellow Sea
}

Correspondence

Jin-Woo Bae

baejw@kribb.re.kr

\author{
Ho-Won Chang, ${ }^{1,2}$ Young-Do Nam, ${ }^{1,3}$ Hyuk-Yong Kwon, ${ }^{1}$ Ja Ryeong Park, ${ }^{1}$ \\ Jung-Sook Lee, ${ }^{1}$ Jung-Hoon Yoon, ${ }^{4}$ Kwang-Guk An ${ }^{2}$ and Jin-Woo Bae ${ }^{1,3,5}$ \\ ${ }^{1}$ Biological Resource Center, KRIBB, Daejeon 305-806, Korea \\ ${ }^{2}$ Department of Biology, Chungnam National University, Daejeon 306-764, Korea \\ ${ }^{3}$ University of Science and Technology, Daejeon 305-333, Korea \\ ${ }^{4} 21$ C Frontier Microbial Genomics and Applications Center, KRIBB, Daejeon 305-806, Korea \\ ${ }^{5}$ Environmental Biotechnology National Core Research Center, Gyeongsang National University, \\ Jinju 660-701, Korea
}

\begin{abstract}
A moderately halophilic, aerobic, Gram-negative bacterium was isolated from a tidal flat area of Dae-Chun, Chung-Nam, Korea. The strain, designated mano $11^{\top}$, comprised rod-shaped cells that were motile by means of polar flagella. It grew with $3-12 \% \mathrm{NaCl}$ and at $4-37^{\circ} \mathrm{C}$ and $\mathrm{pH} 5.3-9.3$. The predominant menaquinone present in this strain was MK-7 and diaminopimelic acid was not found in the cell-wall peptidoglycan. A phylogenetic analysis based on 16S rRNA gene sequences showed that strain mano $11^{\top}$ belongs to the genus Marinobacterium. Strain mano $11^{\top}$ exhibited 92.8-98.3\% 16S rRNA gene sequence similarity when compared with the type strains of three other species of the genus Marinobacterium. DNA-DNA hybridization between strain mano $11^{\top}$ and Marinobacterium georgiense DSM $11526^{\top}$, its closest relative in terms of $16 \mathrm{~S}$ rRNA gene sequence similarity, was $13 \%$. On the basis of the phenotypic, genetic and phylogenetic data, strain mano $11^{\top}$ represents a novel species of the genus Marinobacterium, for which the name Marinobacterium halophilum sp. nov. is proposed. The type strain is mano $11^{\top}(=\mathrm{KCTC}$ $12240^{\top}=$ DSM $17586^{\top}$ ).
\end{abstract}

Halophilic bacteria can be found in habitats representing a wide range of salt concentrations, from marine biotopes to hypersaline environments (Ollivier et al., 1994). The western and south-western coasts of the Korean peninsula consist primarily of tidal flats, which are also known as getbol (Kim et al., 2004). Getbol are unique among other marine sediments as they are alternately undergoing flooding with seawater and exposure to the atmosphere (Kim et al., 2005). Recently, a variety of bacterial species were isolated from Korean getbol and identified as phylogenetically novel micro-organisms (Baik et al., 2005; Yi et al., 2003; Yi \& Chun, 2004; Yoon et al., 2004). To elucidate the bacterial diversity of Korean getbol, we have searched for novel micro-organisms in these sediments. Among the different isolates obtained was a novel Marinobacterium-like strain, designated mano $11^{\mathrm{T}}$. In this study, the taxonomic position of this novel strain was determined using phenotypic, genetic and chemotaxonomic analyses.

Strain mano $11^{\mathrm{T}}$ was isolated from a tidal flat area of DaeChun, Chung-Nam, Korea ( $\left.36^{\circ} 17^{\prime} 45.2^{\prime \prime} \mathrm{N} 126^{\circ} 31^{\prime} 9.5^{\prime \prime} \mathrm{E}\right)$,

The GenBank/EMBL/DDBJ accession number for the 16S rRNA gene sequence of strain mano $11^{\top}$ is $A Y 563030$. using the dilution plating technique. It was grown at $25^{\circ} \mathrm{C}$ for 3 days on marine agar (Difco) plates or marine salts basal medium (MB; Baumann \& Baumann, 1981) supplemented with various carbon sources. Its closest relative in terms of 16S rRNA gene sequence similarity, Marinobacterium georgiense DSM $11526^{\mathrm{T}}$, which was used as a reference strain, was obtained from the Deutsche Sammlung von Mikroorganismen und Zellkulturen (Braunschweig, Germany) and grown under the same conditions. All phenotypic growth tests were carried out with the novel isolate and M. georgiense DSM $11526^{\mathrm{T}}$. Bacterial cultures of the isolate and the reference strain were stored at $-80{ }^{\circ} \mathrm{C}$ on MB containing $20 \%$ glycerol. For morphological and physiological characterization, strain mano $11^{\mathrm{T}}$ and the reference strain were generally cultivated in $\mathrm{MB}$ at $25^{\circ} \mathrm{C}$ with shaking. API 20E, API 20NE and API ZYM test strips (bioMérieux) were used to analyse these bacterial strains biochemically and physiologically and other biochemical tests were performed using the methods and media described by Gordon et al. (1973). The ability to grow on various carbon sources was tested as described by Gonzalez et al. (1997). Catalase activity was determined by means of bubble production in a $3 \%(\mathrm{v} / \mathrm{v}) \mathrm{H}_{2} \mathrm{O}_{2}$ solution. Oxidase activity was determined using an oxidase reagent 
(bioMérieux). Growth under anaerobic conditions was determined after incubation for 7 days in anaerobic GasPak jars (BBL) containing an atmosphere comprising $\mathrm{N}_{2} / \mathrm{CO}_{2} /$ $\mathrm{H}_{2}(80: 10: 10)$. Growth at various $\mathrm{NaCl}$ concentrations, temperatures and $\mathrm{pH}$ values was measured in MB. Cellular morphology and sporulation were investigated using microscopy (E600; Nikon). Cellular motility was observed for the novel isolate in fresh wet mounts of young bacterial cultures (grown in $\mathrm{MB}$ ) by means of the hanging drop method. For observation using transmission electron microscopy, cells from exponentially growing cultures were negatively stained with $1 \%(\mathrm{w} / \mathrm{v})$ phosphotungstic acid. After being air-dried, the grid was examined using a transmission electron microscope (H-7600; Hitachi). Isoprenoid quinones of the mano $11^{\mathrm{T}}$ strain were extracted from $100 \mathrm{mg}$ aliquots of freeze-dried cells according to methods described previously (Collins \& Jones, 1981); they were then purified via preparative TLC (silica gel F254; Merck). The ubiquinone fraction was also analysed by HPLC (L-5000; Hitachi) using a reversed-phase column (YMC pack ODS-AM; YMC), as described previously (Shin et al., 1996). Bacterial strains grown on marine agar for 3 days at $25^{\circ} \mathrm{C}$ were used for the analysis of fatty acid methyl esters, which were extracted and prepared according to standard protocols provided by the MIDI/Hewlett Packard Microbial Identification System (Sasser, 1990). Chromosomal DNA was extracted and purified as described by Sambrook et al. (1989). The $16 \mathrm{~S}$ rRNA gene was amplified by a PCR using two universal primers, as previously described (Stackebrandt et al., 1993). Sequencing of the amplified 16S rRNA gene and phylogenetic analysis were performed according to the methods described by Yoon et al. (1998). DNA-DNA hybridization was performed according to previously described methods (Ezaki et al., 1989). The $16 \mathrm{~S}$ rRNA gene sequence of mano $11^{\mathrm{T}}$ was aligned with 13 reference sequences from the Ribosomal Database Project (Fig. 1), using the multiple sequence-alignment program CLUSTAL_X (1.8) (Thompson et al., 1997). Phylogenetic relationships between representatives of the genus Marinobacterium were determined using MEGA, version 2.1. Distance matrices were determined according to the assumptions described by Kimura (1980). These matrices were used to elaborate dendrograms using the neighbourjoining method (Saitou \& Nei, 1987). To investigate the stability of the trees, a bootstrap analysis was performed. The consensus tree obtained was based on 1000 randomly generated trees.

The morphological, cultural, physiological and biochemical characteristics of strain mano $11^{\mathrm{T}}$ and related species are shown in Table 1 and are provided in the species description (below). Strain mano1 $11^{\mathrm{T}}$ grew at temperatures from 4 to $37^{\circ} \mathrm{C}$, but not at temperatures below $4{ }^{\circ} \mathrm{C}$ or above $37^{\circ} \mathrm{C}$; it grew at $\mathrm{pH} 5.3-8.8$ but not at $\mathrm{pH}$ values below 4.1 or above 9.3. Growth was observed in the presence of $3-12 \% \mathrm{NaCl}$ and very weak growth was observed at $\mathrm{NaCl}$ concentrations of $1-2 \%$. No growth was detected at $\mathrm{NaCl}$ concentrations below $1 \%$ or above $15 \%$. However, growth of M. georgiense DSM $11526^{\mathrm{T}}$ occurred at $\mathrm{NaCl}$ concentrations from 0.5 to $11.4 \%$ (Gonzalez et al., 1997). The novel isolate did not

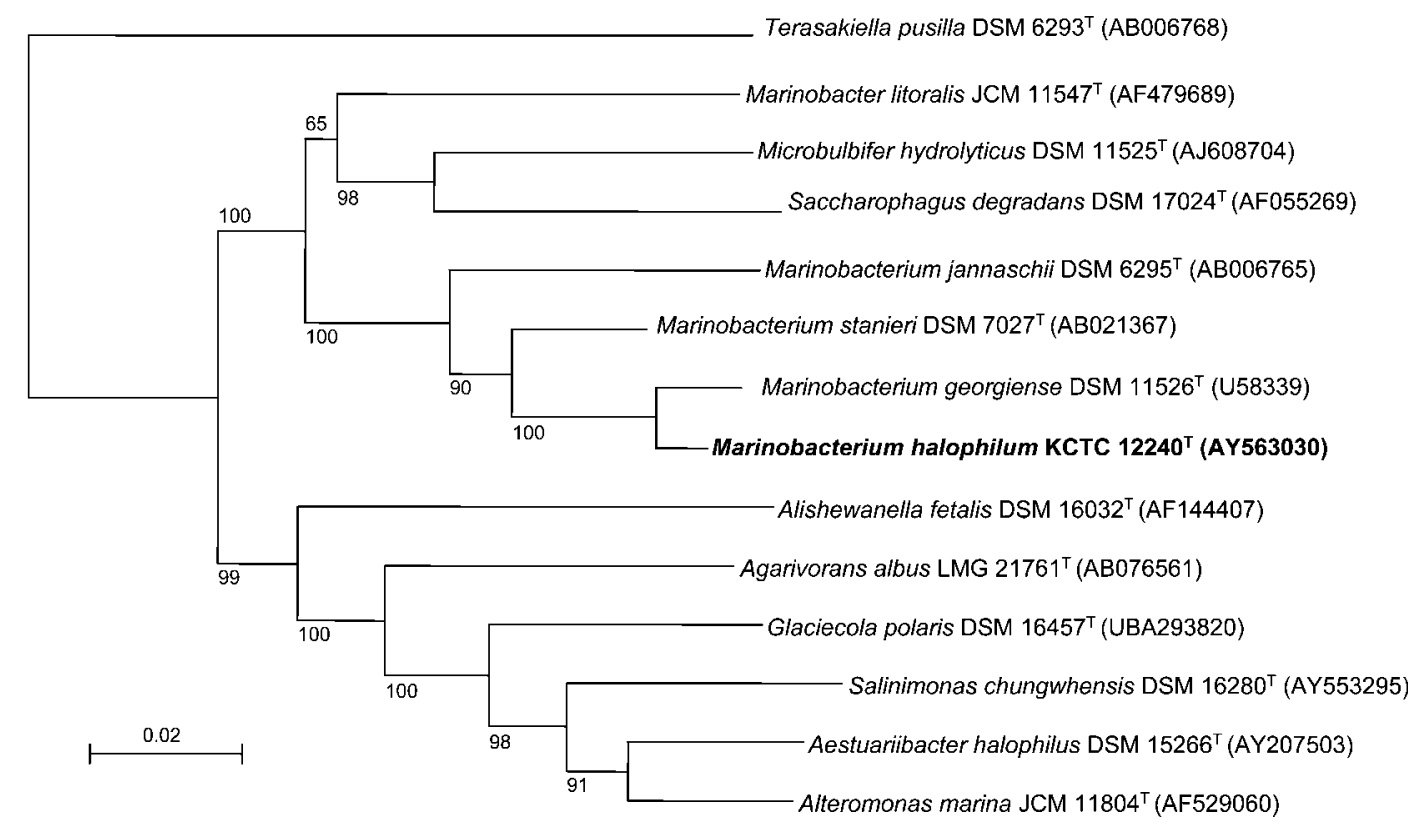

Fig. 1. Consensus phylogenetic tree, based on 16S rRNA gene sequences, showing the relationship between strain mano $11^{\top}$, type strains of different Marinobacterium species and representatives of related genera. The tree was constructed using the neighbour-joining method and $p$-distance. Bootstrap analyses were performed with 1000 repetitions and only values $>50 \%$ are shown. GenBank accession numbers are shown in parentheses. Bar, 0.02 substitutions per nucleotide position. 
Table 1. Taxonomic characteristics of novel isolate mano $11^{\top}$ and type strains of the genus Marinobacterium

Taxa: 1, M. georgiense DSM $11526^{\mathrm{T}} ; 2$, M. jannaschii DSM $6296^{\mathrm{T}}$ (data from Bowditch et al., 1984); 3, M. stanieri DSM $7027^{\mathrm{T}}$ (Baumann et al., 1983); 4, M. halophilum sp. nov. mano11 ${ }^{\mathrm{T}}$. Data for M. georgiense and strain manol1 $1^{\mathrm{T}}$ are from this study. +, Positive reaction; -, negative reaction; ND, not determined. All of the taxa are motile by means of single polar flagellum, rodshaped, aerobic, oxidase-positive, catalase-positive, unable to reduce nitrate, utilize citrate and possess quinone type Q-8.

\begin{tabular}{|lcccc|}
\hline Characteristic & $\mathbf{1}$ & $\mathbf{2}$ & $\mathbf{3}$ & $\mathbf{4}$ \\
\hline Growth at $35{ }^{\circ} \mathrm{C}$ & + & - & + & + \\
Arginine dihydrolase & + & + & - & + \\
Production of: & & & & \\
$\quad$ Acetoin & + & $\mathrm{ND}$ & $\mathrm{ND}$ & + \\
Gelatinase & + & + & - & - \\
Lipase & $\mathrm{ND}$ & - & - & - \\
Utilization of: & & & & \\
Caprate & - & + & + & - \\
Citrate & + & + & + & + \\
Glucose & + & - & - & - \\
Mannitol & - & - & $\mathrm{ND}$ & - \\
Rhamnose & - & $\mathrm{ND}$ & $\mathrm{ND}$ & - \\
Sucrose & - & - & $\mathrm{ND}$ & - \\
\hline
\end{tabular}

grow under anaerobic conditions, gave a negative VogesProskauer test and showed catalase, oxidase and urease activities. Although Marinobacterium jannaschii DSM $6295^{\mathrm{T}}$ and Marinobacterium stanieri DSM $7027^{\mathrm{T}}$ were able to reduce nitrate to nitrite, strain mano $11^{\mathrm{T}}$ could not. Colonies of strain mano $11^{\mathrm{T}}$ were pale orange to yellow, whereas those of M. georgiense DSM $11526^{\mathrm{T}}$ were translucent. Strain mano11 $1^{\mathrm{T}}$ grew on the following carbon sources: glucose, mannose, malate, hydroxybutyrate, citrate and phenylacetate. Substances not utilized for growth included sucrose, rhamnose, lactose, $\mathrm{N}$-acetyl-D-glucosamine, L-arginine and glycine. Isolate mano $11^{\mathrm{T}}$ hydrolysed Tween 80 but not chitin. The characteristics that differentiate the novel isolate from related species are shown in Table 1 . The fatty acid methyl esters of mano1 $1{ }^{\mathrm{T}}$ were identified as $\mathrm{C}_{16: 1} \omega 7 c$ (43.2\%), $\mathrm{C}_{16: 0}(21.9 \%), \mathrm{C}_{18: 1} \omega 7 c(15.7 \%), \mathrm{C}_{10: 0} 3-\mathrm{OH}$ $(7.6 \%), \mathrm{C}_{12: 0}(4.6 \%), \mathrm{C}_{10: 0}(4.3 \%)$ and $\mathrm{C}_{14: 0}(1.6 \%)$.

Phylogenetic trees based on 16S rRNA gene sequences from members of different genera of the Alteromonadaceae (the family that contains the genus Marinobacterium), showed that strain mano $11^{\mathrm{T}}$ falls within a cluster comprising Marinobacterium species (Fig. 1). Strain mano $11^{\mathrm{T}}$ exhibited $16 \mathrm{~S}$ rRNA gene sequence similarities of $92.8-98.3 \%$ with respect to the type strains of three Marinobacterium species. DNA-DNA relatedness studies were performed to determine the genomic relationship between strain mano $11^{\mathrm{T}}$ and M. georgiense DSM $11526^{\mathrm{T}}$, its closest relative in terms of $16 \mathrm{~S}$ rRNA gene sequence similarity. The mean level of DNADNA relatedness observed between these two strains was
$13 \%$. Therefore, taken together, the phylogenetic and DNA-DNA hybridization results suggest that strain mano $11^{\mathrm{T}}$ represents a novel species of the genus Marinobacterium, for which the name Marinobacterium halophilum sp. nov. is proposed.

\section{Description of Marinobacterium halophilum sp. nov.}

Marinobacterium halophilum (ha.lo'phi.lum. Gr. n. halos salt; Gr. adj. philos loving; N.L. neut. adj. halophilum salt-loving).

Cells are rods with overall dimensions of $0.5-0.7 \mu \mathrm{m}$ (width) and 2.1-3.0 $\mu \mathrm{m}$ (length) in 3-day-old cultures growing at $25^{\circ} \mathrm{C}$ on marine agar plates. Gram-negative and motile. Colonies are pale orange to yellow, measure $2-3 \mathrm{~mm}$ in diameter and are smooth, round or slightly irregular in shape after 5 days culture on Luria-Bertani agar plates. Growth occurs in the presence of $3-12 \% \mathrm{NaCl}$, but no growth is observed in the absence of $\mathrm{NaCl}$ or when supplemented with $15 \% \mathrm{NaCl}$. Growth occurs at $45^{\circ} \mathrm{C}$ and at $\mathrm{pH}$ 5.3-9.3. Casein and starch are hydrolysed. Acid is produced from sucrose, fructose, raffinose, mannitol, ribose, glycerol, mannose, lactose, glucose, maltose and trehalose. Acid is not produced from dulcitol, galactose, inulin, D-arabitol, rhamnose, arabinose, sorbitol or Dxylose. Using the API ZYM system, activity is detected for alkaline phosphatase, esterase (C4), esterase lipase (C8), leucine arylamidase, acid phosphatase and naphthol-AS-BIphosphohydrolase. No activity is detected for lipase (C14), valine arylamidase, cystine arylamidase, trypsin, $\alpha$-chymotrypsin, $\alpha$-galactosidase, $\beta$-galactosidase, $\beta$-glucuronidase, $\beta$-glucosidase, $\alpha$-glucosidase, $\beta$-glucosidase, $N$-acetyl- $\beta$ glucosaminidase, $\alpha$-mannosidase or $\alpha$-fucosidase. Diaminopimelic acid is not present in the cell-wall peptidoglycan and the predominant quinone is $\mathrm{Q}-8$. The predominant fatty acids are $\mathrm{C}_{16: 1} \omega 7 c$ and $\mathrm{C}_{16: 0}$ (43.2 and $21.9 \%$, respectively).

The type strain, strain mano $11^{\mathrm{T}}\left(=\mathrm{KCTC} 12240^{\mathrm{T}}=\mathrm{DSM}\right.$ $\left.17586^{T}\right)$, was isolated from a tidal flat area of Dae-Chun, Chung-Nam, Korea.

\section{Acknowledgements}

The authors are supported by grant BDM0200524, NNM0100512, KRIBB Research Initiative Program and Environmental Biotechnology National Core Research Center (KOSEF: R15-2003-012-02002-0) from the Ministry of Science and Technology (MOST) of the Republic of Korea.

\section{References}

Baik, K. S., Seong, C. N., Kim, E. M., Yi, H., Bae, K. S. \& Chun, J. (2005). Hahella ganghwensis sp. nov., isolated from tidal flat sediment. Int J Syst Evol Microbiol 55, 681-684.

Baumann, P. \& Baumann, L. (1981). The Marine Gram-Negative Eubacteria: Genera Photobacterium, Beneckea, Alteromonas, Pseudomonas, and Alcaligenes. Berlin: Springer. 
Baumann, P., Bowditch, R. D., Baumann, L. \& Beaman, B. (1983). Taxonomy of marine Pseudomonas species: P. stanieri sp. nov.; P. perfectomarina sp. nov., nom. rev.; P. nautica; and P. doudoroffii. Int J Syst Bacteriol 33, 857-865.

Bowditch, R. D., Baumann, L. \& Baumann, P. (1984). Description of Oceanospirillum kriegii sp. nov. and O. jannaschii sp. nov. and assignment of two species of Alteromonas to this genus as $O$. commune comb. nov. and O. vagum comb. nov. Curr Microbiol 10, 221-230.

Collins, M. D. \& Jones, D. (1981). Distribution of isoprenoid quinone structural types in bacteria and their taxonomic implication. Microbiol Rev 45, 316-354.

Ezaki, T., Hashimoto, Y. \& Yabuuchi, E. (1989). Fluorometric deoxyribonucleic acid-deoxyribonucleic acid hybridization in microdilution wells as an alternative to membrane filter hybridization in which radioisotopes are used to determine genetic relatedness among bacterial strains. Int J Syst Bacteriol 39, 224-229.

Gonzalez, J. M., Mayer, F., Moran, M. A., Hodson, R. E. \& Whitman, W. B. (1997). Microbulbifer hydrolyticus gen. nov., sp. nov., and Marinobacterium georgiense gen. nov., sp. nov., two marine bacteria from a lignin-rich pulp mill waste enrichment community. Int J Syst Bacteriol 47, 369-376.

Gordon, R. E., Haynes, W. C. \& Pang, C. H. (1973). The Genus Bacillus. Washington, DC: Agricultural Research Service.

Kim, B. S., Oh, H. M., Kang, H., Park, S. S. \& Chun, J. (2004). Remarkable bacterial diversity in the tidal flat sediment as revealed by $16 \mathrm{~S}$ rDNA analysis. J Microbiol Biotechnol 14, 205-211.

Kim, B. S., Oh, H. M., Kang, H. \& Chun, J. (2005). Archaeal diversity in tidal flat sediment as revealed by $16 \mathrm{~S}$ rDNA analysis. J Microbiol 43, 144-151.

Kimura, M. (1980). A simple method for estimating evolutionary rates of base substitutions through comparative studies of nucleotide sequences. J Mol Evol 16, 111-120.
Ollivier, B., Caumette, P., Garcia, J. L. \& Mah, R. A. (1994) Anaerobic bacteria from hypersaline environments. Microbiol Rev 58, 27-38.

Saitou, N. \& Nei, M. (1987). The neighbor-joining method: a new method for reconstructing phylogenetic trees. Mol Biol Evol 4, 406-425.

Sambrook, J., Fritsch, E. F. \& Maniatis, T. (1989). Molecular Cloning: a Laboratory Manual, 2nd edn. Cold Spring Harbor, NY: Cold Spring Harbor Laboratory.

Sasser, M. (1990). Identification of Bacteria by Gas Chromatography of Cellular Fatty Acids, MIDI Technical Note 101. Newark, DE: MIDI Inc.

Shin, Y. K., Lee, J.-S., Chun, C. O., Kim, H.-J. \& Park, Y.-H. (1996). Isoprenoid quinone profiles of the Leclercia adecarboxylate KCTC $1036^{\mathrm{T}}$. J Microbiol Biotechnol 6, 68-69.

Stackebrandt, E., Liesack, W. \& Goebel, B. M. (1993). Bacterial diversity in a soil sample from a subtropical Australian environment as determined by $16 \mathrm{~S}$ rDNA analysis. FASEB J 7, 232-236.

Thompson, J. D., Gibson, T. J., Plewniak, F., Jeanmougin, F. \& Higgins, D. G. (1997). The CLUSTAL_X windows interface: flexible strategies for multiple sequence alignment aided by quality analysis tools. Nucleic Acids Res 25, 4876-4882.

Yi, H. \& Chun, J. (2004). Hongiella mannitolivorans gen. nov., sp. nov., Hongiella halophila sp. nov. and Hongiella ornithinivorans sp. nov., isolated from tidal flat sediment. Int J Syst Evol Microbiol 54, 157-162.

Yi, H., Chang, Y. H., Oh, H. W., Bae, K. S. \& Chun, J. (2003). Zooshikella ganghwensis gen. nov., sp. nov., isolated from tidal flat sediments. Int J Syst Evol Microbiol 53, 1013-1018.

Yoon, J. H., Lee, S. T. \& Park, Y. H. (1998). Inter- and intraspecific phylogenetic analysis of the genus Nocardioides and related taxa based on 16S rDNA sequences. Int J Syst Bacteriol 48, 187-194.

Yoon, J. H., Oh, T. K. \& Park, Y. H. (2004). Kangiella koreensis gen. nov., sp. nov. and Kangiella aquimarina sp. nov., isolated from a tidal flat of the Yellow Sea in Korea. Int J Syst Evol Microbiol 54, 1829-1835. 